\title{
Atmospheric Blocking in the South Atlantic during the Summer 2014: A Synoptic Analysis of the Phenomenon
}

\author{
Wanderson Luiz Silva1,2, Mariana X. Nascimento'1, Wallace F. Menezes1 \\ ${ }^{1}$ Department of Meteorology, Federal University of Rio de Janeiro, Rio de Janeiro, Brazil \\ ${ }^{2}$ Electric Energy Research Center-Eletrobras Cepel, Rio de Janeiro, Brazil \\ Email: wanderson@ufrj.br, marianaximenesn@gmail.com, wallace.menezes@gmail.com
}

Received 24 August 2015; accepted 6 October 2015; published 9 October 2015

Copyright ( 2015 by authors and Scientific Research Publishing Inc.

This work is licensed under the Creative Commons Attribution International License (CC BY). http://creativecommons.org/licenses/by/4.0/

(c) (i) Open Access

\begin{abstract}
Under conditions of atmospheric blocking, the presence of a quasi-stationary anticyclone of large amplitude disrupts the normal eastward progression of the synoptic systems. These blockings correspond mainly to a positive anomaly of the air pressure. As a result, in the regions affected by the blocking occur several consecutive dry days and temperatures above average. This paper aims to discuss synoptically the atmospheric blocking phenomenon occurred in January and February 2014 in the South Atlantic Ocean, affecting especially the Southeastern Brazil and sectors that depend on the quantity of water for their activities in the region, such as agriculture and electricity generation. The significant population concentration makes this area emphatically vulnerable to long periods of drought, especially during the summer, affecting the water supply for the population. In order to achieve this goal, data of geopotential height at 850/500 $\mathrm{hPa}$, streamlines in $850 / 500 \mathrm{hPa}$, pressure, temperature, humidity and wind at surface were evaluated through NCEP/ NCAR reanalysis (CFSRv2-Climate Forecast System Reanalysis Version 2) with $0.2^{\circ} \times 0.2^{\circ}$ resolution. The analysis showed that the stationary anticyclone was configured dynamically favorable to blocking in the lower and middle levels of the atmosphere. Thus, atmospheric pressure at mean sea level presented values above normal combined with high average air temperature. By the climatological analysis, it was noted that there were emphatic negative precipitation anomalies over Southeastern Brazil. This atmospheric blocking was characterized as anomalous due to its long duration in a considered rainy season.
\end{abstract}

\section{Keywords}

Atmospheric Blocking, Drought, Heat Wave, South Atlantic, Southeastern Brazil, Summer 2014

How to cite this paper: Luiz Silva, W., Nascimento, M.X. and Menezes, W.F. (2015) Atmospheric Blocking in the South Atlantic during the Summer 2014: A Synoptic Analysis of the Phenomenon. Atmospheric and Climate Sciences, 5, 386-393. http://dx.doi.org/10.4236/acs.2015.54030 


\section{Introduction}

The atmospheric circulation at high levels in mid-latitudes is qualified by a prevailing west zonal flow which provides maintenance and displacement eastward of synoptic systems such as fronts, cyclones and anticyclones [1]. On the other hand, in atmospheric blocking circumstances, a quasi-stationary anticyclone of relevant range performs around $45^{\circ}$ latitude, suspending the usual succession of synoptic systems eastward [2]. An atmospheric circulation feature related to the blocking condition is the partition of the jet stream into two branches, which causes an interruption of the zonal pattern and abstains the shift of the synoptic phenomena [3].

The synoptic systems are weakened in the context of an atmospheric blocking, becoming meridionally amplified and zonally contracted as they approach by the west of obstructed area, so they are stationary or they are diverted to northeast or southeast, ending up to surround the blocking anticyclone [4]. Throughout this process, there is the dispersion of these synoptic phenomena in the region under the atmospheric blocking, and the jet stream moves toward the higher latitudes (Figure 1), compelling the route of transient atmospheric disturbances, which are thus invigorated.

The challenge of determining a singular principle that explains the formation, maintenance and dissipating of an atmospheric blocking, as well as the possibility to improve and expand the weather forecast term of this phenomenon in order to mitigate its consequences has been noticeably stimulating various researchers to study the system. In this context, this paper aims to discuss from the synoptic point of view the atmospheric blocking occurred in January and February 2014 over the South Atlantic Ocean, significantly affecting the Southeast of Brazil, a fact that sparked a dramatic crisis in supply water in the region.

\section{Methodology}

\subsection{Study Area}

The study area of this work comprises South America and South Atlantic Ocean, since the atmospheric blocking in question (summer 2014) refers to a synoptic scale system. The Southeast region of Brazil (Figure 2) is treated as the central focus of the biggest impacts of this phenomenon. According to the Brazilian Institute of Geography and Statistics (IBGE), this is the most populous region in the country with about 85 million inhabitants, corresponding to $43 \%$ of the total population of the territory, aggregating large and important cities as São Paulo and Rio de Janeiro. This population concentration makes the Southeast highly susceptible to weather and climatic conditions, as they regulate important economic activities in the region, such as agriculture, urban planning and electricity generation.

The climate in the Southeast region is tropical, with two well characterized periods: one that concentrates much of the rain (October to March) and another, with a marked decrease in rainfall (April to September). The rainfall distribution is strongly influenced by geographical predicates of the landscape and the dynamics of atmospheric systems operating in the area [6].

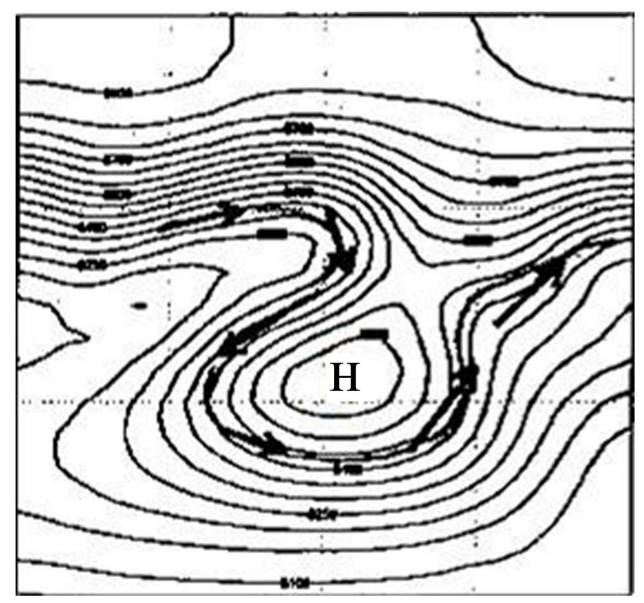

Figure 1. Atmospheric flow in the presence of a blocking system (high pressure) in the Southern Hemisphere [5]. 


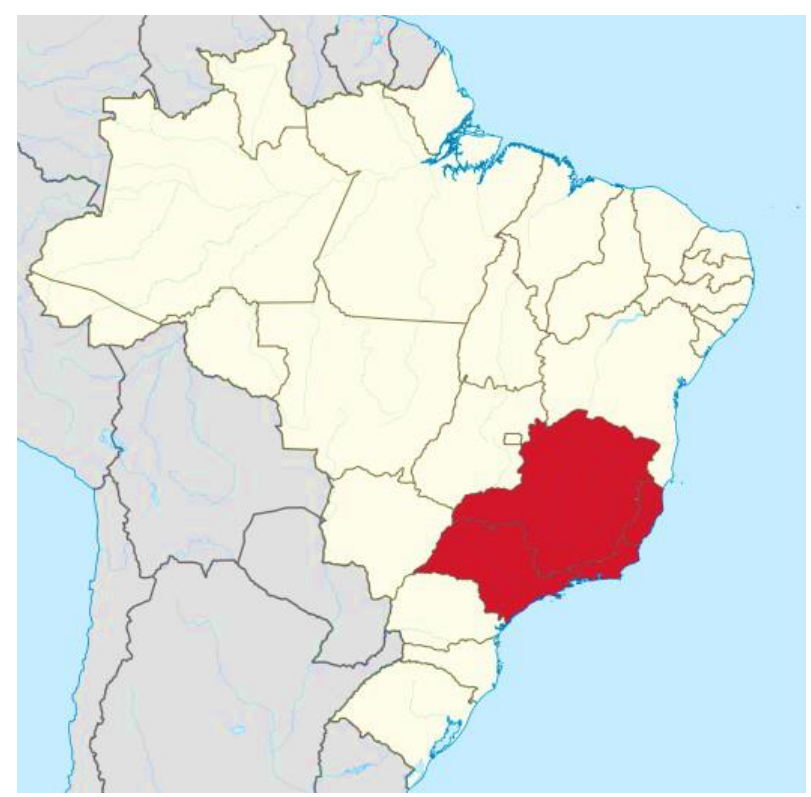

Figure 2. Southeast region of Brazil (in red) and adjacent South Atlantic Ocean.

\subsection{Data}

The data used to assess the atmospheric blocking occurred in summer 2014 are from the high-resolution reanalysis of the National Centers for Environmental Prediction/National Center for Atmospheric Research (NCEP/ NCAR), CFSRv2 (Climate Forecast System Reanalysis Version 2) with grid resolution of $0.205^{\circ} \times 0.204^{\circ}$ [7] . The CFSRv2 presents a satisfactory representation of climate on seasonal and subseasonal scales, with an extensive set of retrospective forecasts for users who want to calibrate their weather products. Moreover, these reanalysis can be used in climate research to various sectors of society, such as agriculture, water resources and health.

With regard to data analysis, the following mean fields were examined: geopotential height at 850 and 500 $\mathrm{hPa}$, streamlines at 850 and $500 \mathrm{hPa}$, pressure at mean sea level, winds at 10 meters, air temperature on the surface and specific humidity at 2 meters. These variables were verified in January and February 2014 throughout South America and South Atlantic Ocean, in order to capture the synoptic overview of the atmosphere in this period.

\section{Analysis and Discussion}

In blocking conditions, significant anomalies of geopotential are registered in average levels of the atmosphere. Analyzing the geopotential at $500 \mathrm{hPa}$ and their geopotential height irregularities (Figure 3) in January and February 2014, it is noted that the geopotential height showed values around 590 meters, about 30 to 50 meters above normal for summer months. Figure 4 gives the geopotential values at $850 \mathrm{hPa}$, confirming the presence of a high atmospheric pressure of a blocking system. In this situation, the large-scale meridional flow is more intense, with low zonal index circulation, acting as an obstruction to the movement of transient systems.

The anticyclonic circulation was well configured with its streamlines at all levels (850 and $500 \mathrm{hPa}$ ) in January and February 2014 (Figure 5), a fact which supports the definition of a high pressure system considered hot in blocking conditions. Therefore, there was the performance of an atmospheric blocking, where a stationary high pressure cell with barotropic structure persists for at least six consecutive days, as the no objective criterion defined by [8]. In this case, the system tenacity lasted about one month.

Figure 6 shows the mean field of pressure at mean sea level (hPa) along with winds at 10 meters for January and February 2014. The South Atlantic Subtropical Anticyclone, acting as a blocking hot high pressure, remained with daily average value around $1020 \mathrm{hPa}$ for nearly five consecutive weeks between $20^{\circ} \mathrm{S}$ and $40^{\circ} \mathrm{S}$ over the ocean with its western outskirts influencing eloquently the weather in eastern Brazil. Winds from the 

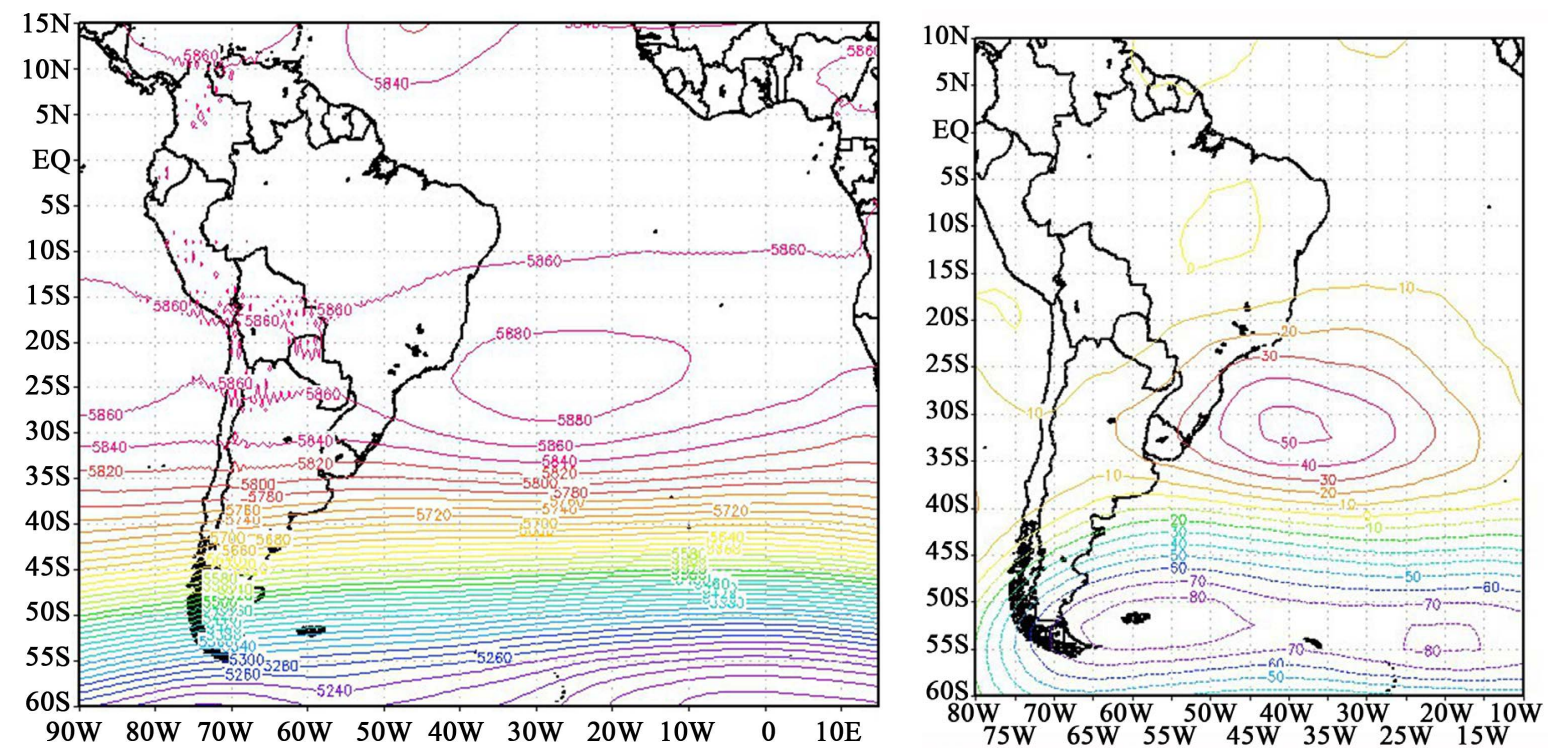

Figure 3. Mean fields of geopotential at $500 \mathrm{hPa}$ (left) and geopotential height anomaly at $500 \mathrm{hPa}$ (right) for January and February 2014.

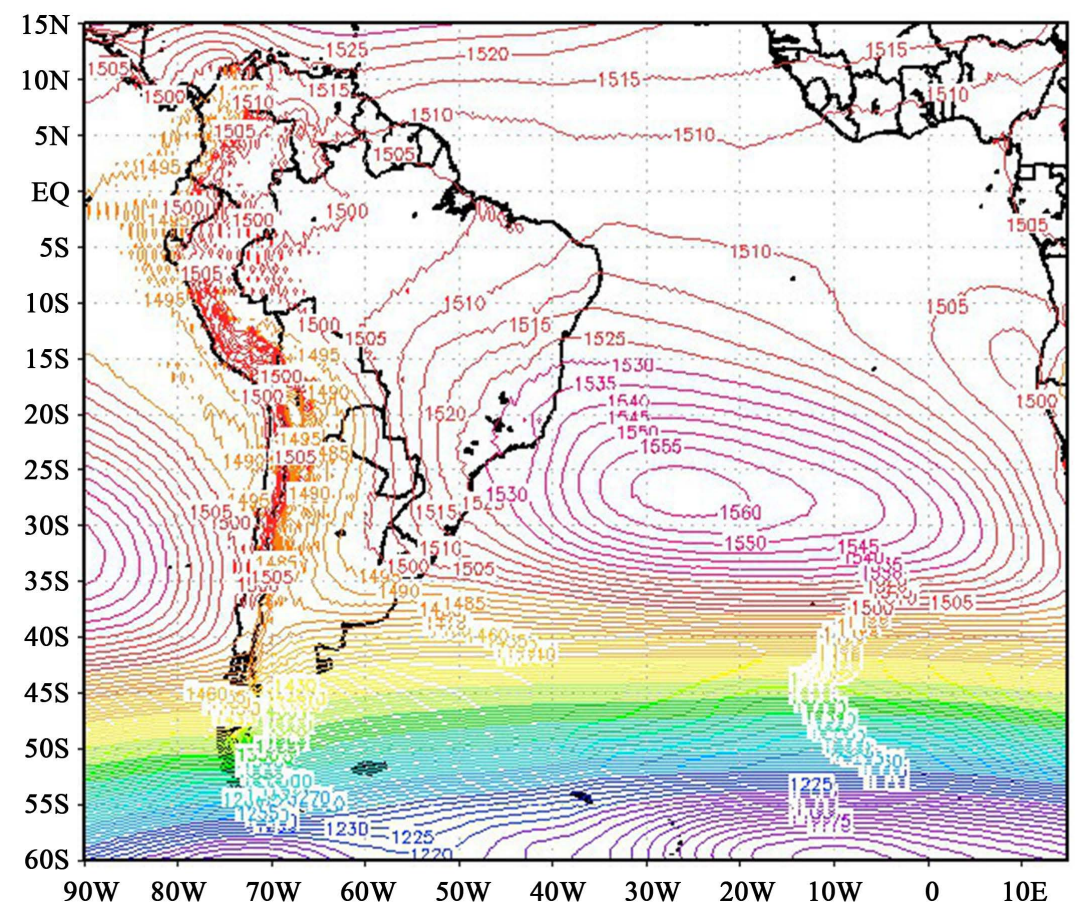

Figure 4. Mean field of geopotential at 850 hPa for January and February 2014.

north and east quadrants predominated over the Southeast of the country between January and mid-February, contributing to the conservation of high temperatures over the region.

As a result of climatic regimes comparison of atmospheric blockings in the Northern (NH) and Southern (SH) hemispheres, it was found that the duration of blockings in the $\mathrm{SH}$ is less than the $\mathrm{NH}$, by the presence of more intense western tropospheric winds at high and mid-latitudes in SH [9]. Moreover, the authors also found that blockings on the SH are, on average, located at lower latitudes than NH. The atmospheric blocking center that established in the summer 2014 was positioned about 30 to $35^{\circ} \mathrm{S}$, i.e., slightly below $45^{\circ} \mathrm{S}$, contributing to the high pressure, the lack of precipitation and the high temperatures in the region of influence (Figure 7). 

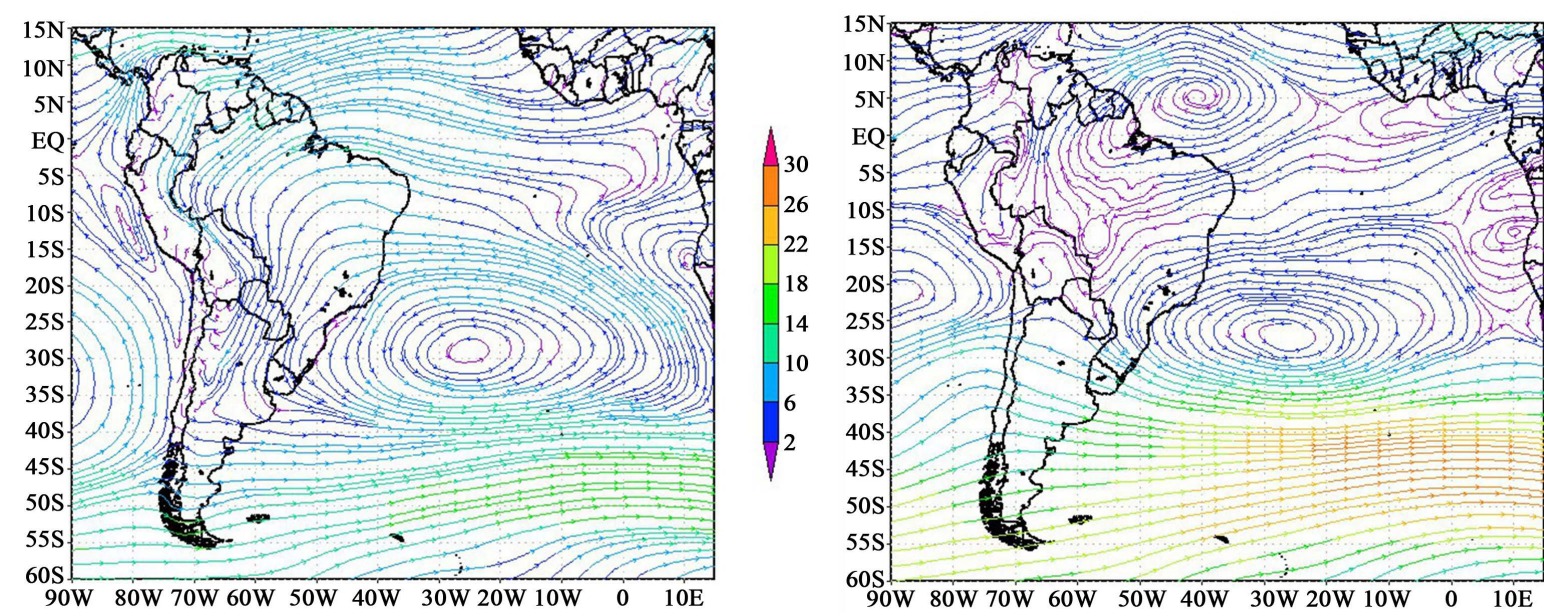

Figure 5. Mean fields of streamlines (m/s) at $850 \mathrm{hPa}$ (left) and $500 \mathrm{hPa}$ (right) for January and February 2014.

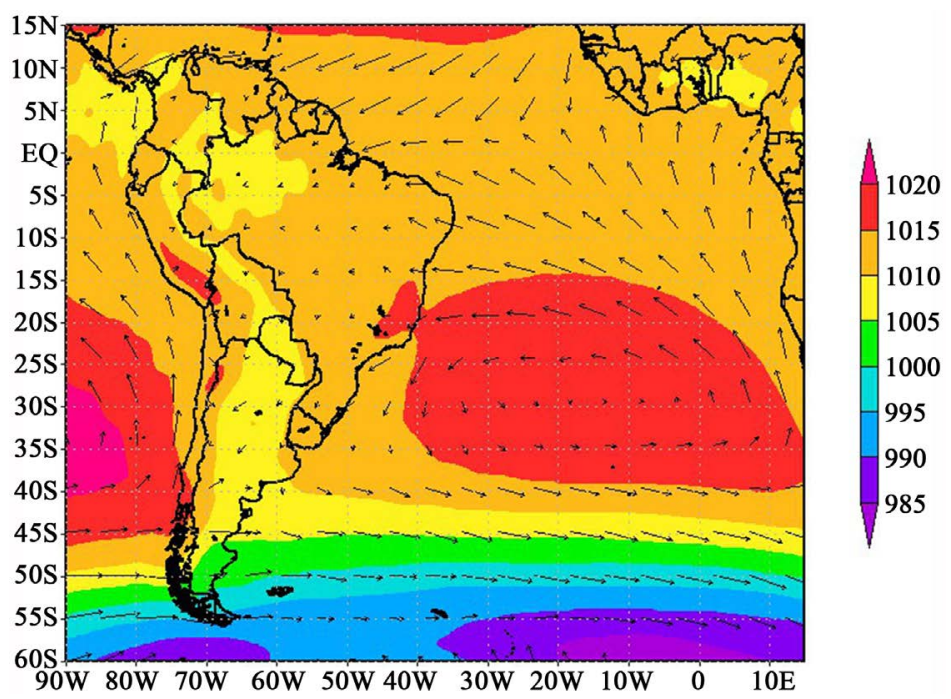

Figure 6. Mean field of pressure at mean sea level (hPa) and wind at 10 meters for January and February 2014.
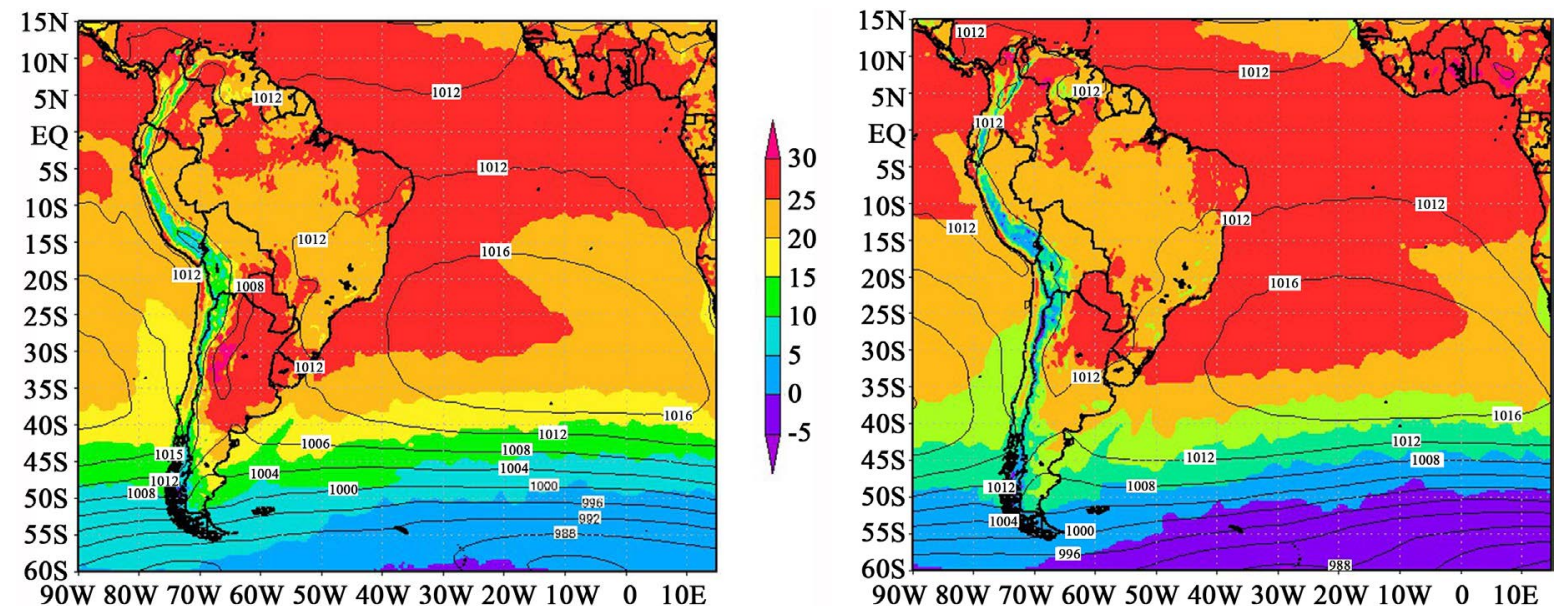

Figure 7. Mean fields of pressure at mean sea level $(\mathrm{hPa})$ and air temperature at surface $\left({ }^{\circ} \mathrm{C}\right)$ for January (left) and February (right) 2014. 
Figure 8 illustrates the air temperature anomalies in January and February 2014. It is noted that the observed temperatures were $1^{\circ} \mathrm{C}$ to $2^{\circ} \mathrm{C}$ above the climatological temperatures. However, it is noteworthy that these values are average and attenuated by the reanalysis parameterization. According to the National Institute of Meteorology (INMET), January 2014 was the warmest month in São Paulo city since 1943, with a mean maximum temperature of $31.9^{\circ} \mathrm{C}$. In the Rio de Janeiro city, January 2014 recorded a mean maximum temperature of $36.2^{\circ} \mathrm{C}$ against the climatological average of $32^{\circ} \mathrm{C}$ in the summer months [10].

The anticyclonic circulation cooperated for a smooth reduction in moisture availability in the eastern sector of Brazil in January and February 2014 (Figure 9). Checking the specific humidity anomalies at 2 meters also in Figure 9, it was noted that there were no significant irregularities over the country during the summer. Although the sufficient moisture in the atmosphere, physical and dynamic conditions associated with the subsidence movement of the blocking high pressure did not allow the development of deep cloudiness and, hence, precipitation. Thus, it was not registered any episode of South Atlantic Convergence Zone (SACZ), the moisture convergent flow in the lower troposphere that is responsible for the peak of the rainy season between December and February in the Midwest and Southeast regions of Brazil [11].

February 2014 was the month in which the absence of rainfall became strongly critical in climatological terms, in addition to installing a vehement concern about the reservoirs that store water to supply the population in Southeastern Brazil. Figure 10 shows the INMET precipitation climatology for Brazil in February [12]. It is observed that the average rainfall is about 180 to $220 \mathrm{~mm}$ in the south-central region of the southeastern country. However, according to the total rainfall in February recorded by CPTEC-Center for Weather Forecast and Climate Studies (Figure 11), the rainfall volume did not exceed $50 \mathrm{~mm}$ in most of the region [13], representing just around 25\% of normal and a negative anomaly of 100 to $200 \mathrm{~mm}$.

It was showed that, for the east and west sectors of South America, the frequency of blockings is higher during the winter and spring months [14]. Wherefore, the atmospheric blocking that developed over the South Atlantic Ocean and energetically acted on the Southeastern Brazil was characterized as anomalous because of its duration of about 30 subsequent days during the summer. This led to an unusual rainy season, with rainfall amounts far below normal.

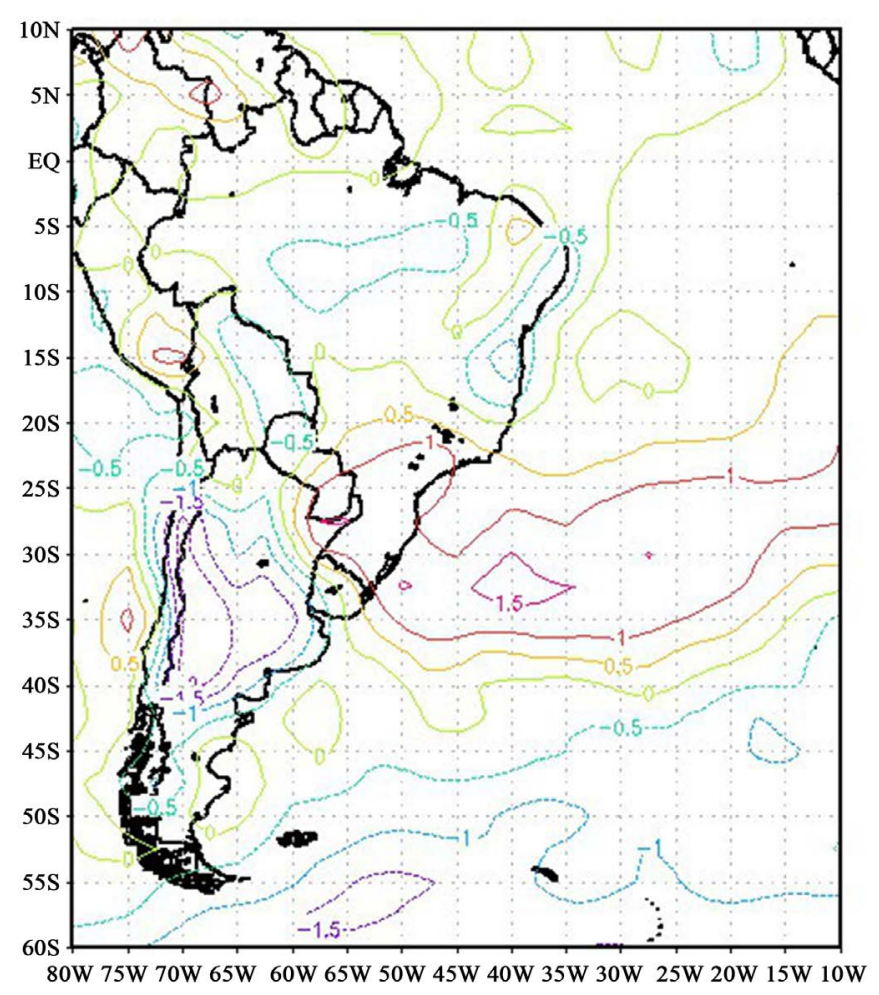

Figure 8. Mean field of air temperature anomalies $\left({ }^{\circ} \mathrm{C}\right)$ for January and February 2014. 

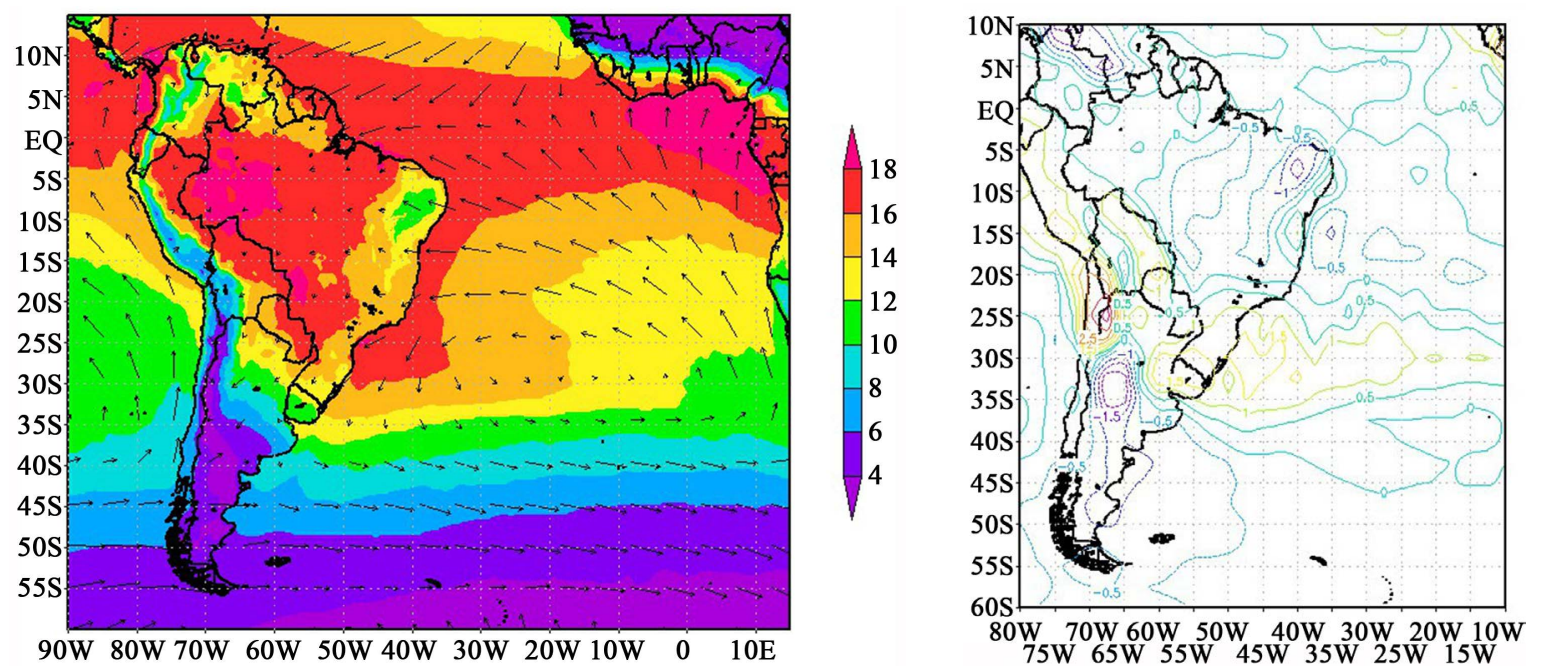

Figure 9. Mean fields of specific humidity at 2 meters $(\mathrm{g} / \mathrm{kg})$ and winds at 10 meters (left) and (right) specific humidity anomalies (g/kg, right) for January and February 2014.

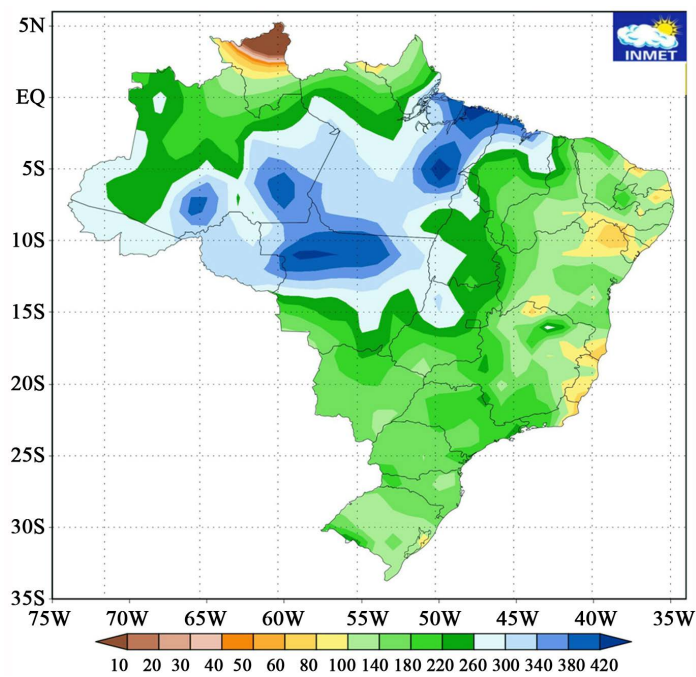

Figure 10. Climatological rainfall (mm) for February 2014 in Brazil [12].
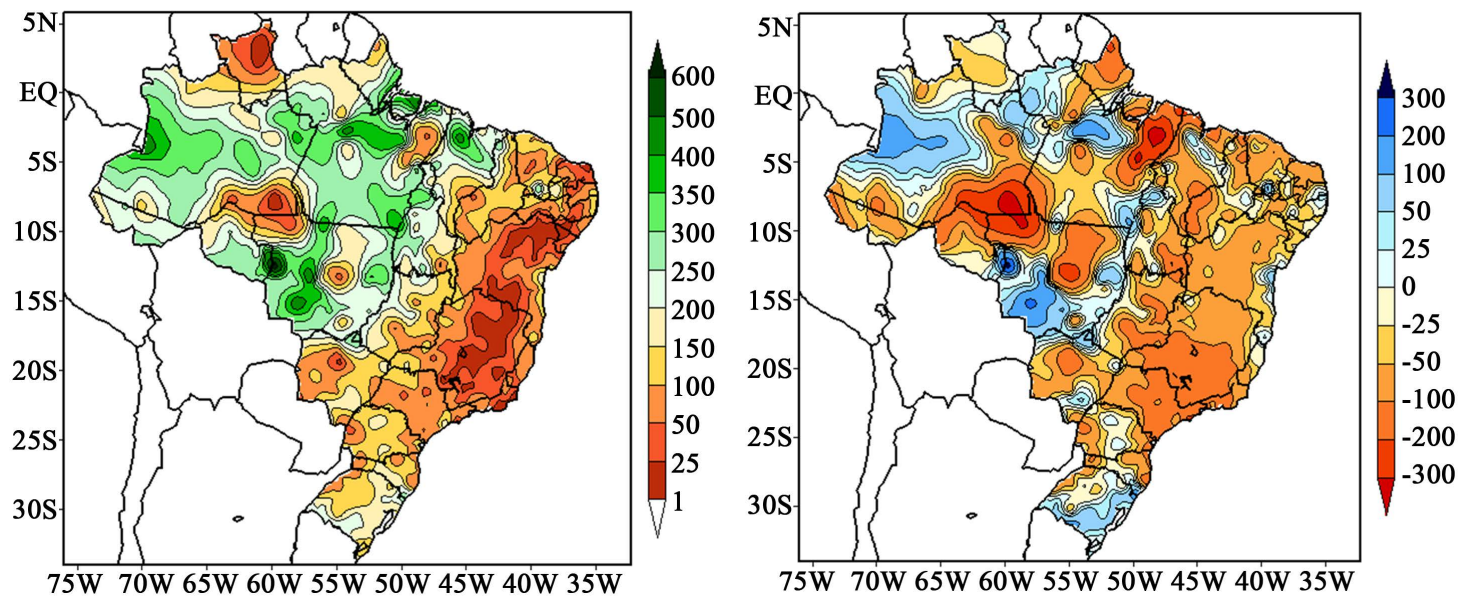

Figure 11. Observed rainfall (mm, left) and rainfall anomalies (mm, right) for February 2014 in Brazil [13]. 


\section{Conclusions}

From a synoptic assessment of geopotential, streamlines, pressure, wind, air temperature, specific humidity and precipitation fields, the atmospheric panorama presented for January and February 2014 over the South Atlantic Ocean is representative of an evident abnormal atmospheric blocking pattern for this period of year. Future investigations must be conducted in order to improve early identification methods in such phenomenon for monthly and seasonal forecast. In addition, it would also be relevant to study remote causes and factors for configuration of blockings that are established over this region, as intraseasonal oscillations.

For meteorologists, the instruction about atmospheric blocking situation has substantial value, because the system continues uninterrupted for several days and the blocking high pressure displacement is relatively mild from one day to another. Therefore, due to the perseverance of local weather conditions, blockings admit achieve superior ability in numerical forecasting of short and medium terms, a fact that represents a wide advantage to sectors such as agriculture, industry, energy, transportation and others, whose management and planning crucially depend on the weather.

\section{References}

[1] Casarin, D.P. (1983) Um Estudo Observacional sobre os Sistemas de Bloqueio no Hemisfério Sul. Masters Dissertation, National Institute for Space Research, 69 p.

[2] Fuentes, M.V. (1997) Climatologia de Bloqueios Próximos à América do Sul e seus Efeitos. Masters Dissertation, National Institute for Space Research, 91 p.

[3] Ambrizzi, T., Marques, R.F.C. and Nascimento, E.L. (2009) Bloqueios Atmosféricos. Tempo e Clima no Brasil, 18, 279-296.

[4] Oliveira, F.N.M. (2011) Climatologia de Bloqueios Atmosféricos no Hemisfério Sul: Observações, Simulações do Clima do Século XX e Cenários Futuros de Mudanças Climáticas. Doctoral Thesis, University of São Paulo, 158 p.

[5] Nascimento, E.L. and Ambrizzi, T. (2002) The Influence of Atmospheric Blocking on the Rossby Wave Propagation in Southern Hemisphere Flows. Journal of the Meteorological Society of Japan, 80, 139-159. http://dx.doi.org/10.2151/jmsj.80.139

[6] Nunes, L.H., Vicente, A.K. and Candido, D.H. (2009) Clima da Região Sudeste do Brasil. Tempo e Clima no Brasil, 16, 243-258.

[7] Saha, S., et al. (2014) The NCEP Climate Forecast System Version 2. Journal of Climate, 27, 2185-2208. http://dx.doi.org/10.1175/JCLI-D-12-00823.1

[8] Van Loon, H. (1956) Blocking Action in the Southern Hemisphere-Part I. Notos, 5, 171-175.

[9] Wiedenmann, J.M., Lupo, A.R., Mokhov, I. and Tikhonova, E.A. (2002) The Climatology of Blocking Anticyclones for the Northern and Southern Hemisphere Block Intensity as a Diagnostic. Journal of Climate, 15, 3459-3473. http://dx.doi.org/10.1175/1520-0442(2002)015<3459:TCOBAF>2.0.CO;2

[10] Luiz Silva, W. and Dereczynski, C.P. (2014) Caracterização Climatológica e Tendências Observadas em Extremos Climáticos no Estado do Rio de Janeiro. Anuário do Instituto de Geociências, Federal University of Rio de Janeiro, 37, 123-138.

[11] Carvalho, L.M.V. and Jones, C. (2009) Zona de Convergência do Atlântico Sul. Tempo e Clima no Brasil, 6, 95-109.

[12] Instituto Nacional de Meteorologia-INMET (2009) Normais Climatológicas do Brasil 1961-1990. In: Ramos, A.M., Santos, L.A.R. and Fortes, L.T.G., Eds., INMET, Brazil, 465 p.

[13] Centro de Previsão de Tempo e Estudos Climáticos_CPTEC (2014) Boletim de Monitoramento e Análise Climática. In: Cavalcanti, I.F.A., Ed., Climanálise, 29.

[14] Marques, R.F.C. (1996) Bloqueio Atmosférico no Hemisfério Sul. Doctoral Thesis, National Institute for Space Research, $158 \mathrm{p}$. 